\title{
THE USE OF TASK-BASED INSTRUCTION TO IMPROVE SPEAKING SKILL TO THE SECOND SEMESTER STUDENTS OF STKIP SILIWANGI BANDUNG ON THE ACADEMIC YEAR OF 2014-2015
}

\author{
${ }^{1)}$ Ningtyas Orilina Argawati, ${ }^{2}$ Trisnendri Syahrizal \\ tyas.orilina@yahoo.com
}

\author{
1.2) Program Studi Pendidikan Bahasa Sastra Inggris, STKIP Siliwangi
}

\begin{abstract}
The speaking capability of the second semester students in STKIP Siliwangi BANDUNG can still be improved since they have chance to change. The college location, the lecturers, and the students' capability itself enable them to get the best result of study. However, they still speak with hesitation since they feel not confidence to speak, or in the other way they lack of motivation. Therefore, this study aims to improve the students speaking skill through Task-based Instruction. This method relays on the use of task to gather students and they have to accomplish the task with their own way. This study consists of two cycles, each cycle consists of pre-test, two meetings treatment, and post-test. From the data taken, the result tends to be good. There is improvement on both the students' ability and motivation. The improvement can be seen on their increasing on their speaking score and in their way they perform their speaking. In conclusion, task can help students to study by their own. It works when it was implemented on the second students of STKIP Siliwangi Bandung.
\end{abstract}

Keywords: Action Research, Speaking Skill, Task-Based Instruction

\begin{abstract}
ABSTRAK
Kemampuan berbicara siswa semester kedua di STKIP Siliwangi BANDUNG masih bisa ditingkatkan karena mereka memiliki kesempatan untuk berubah. Lokasi kampus, dosen, dan kemampuan siswa itu sendiri memungkinkan mereka untuk mendapatkan hasil terbaik dari penelitian. Namun, mereka masih berbicara dengan ragu-ragu karena mereka merasa tidak percaya diri untuk berbicara, atau dengan cara lain mereka kurang motivasi. Oleh karena itu, penelitian ini bertujuan untuk meningkatkan keterampilan siswa berbicara melalui Instruksi Task berbasis. Metode ini relay pada penggunaan tugas untuk mengumpulkan siswa dan mereka harus menyelesaikan tugas dengan cara mereka sendiri. Penelitian ini terdiri dari dua siklus, setiap siklus terdiri dari pre-test, dua pertemuan pengobatan, dan post-test. Dari data yang diambil, hasilnya cenderung baik. Ada perbaikan di kedua kemampuan dan motivasi belajar siswa. Perbaikan dapat dilihat pada mereka meningkat pada skor berbicara dan cara mereka mereka melakukan berbicara mereka. Kesimpulannya, tugas dapat membantu siswa untuk belajar dengan mereka sendiri. Ia bekerja ketika diimplementasikan pada siswa kedua STKIP Siliwangi Bandung.
\end{abstract}

Kata Kunci: Penelitian Tindakan, Keterampilan Berbicara, Task-Based Instruction

\section{A. INTRODUCTION}

Teaching speaking to young learner is somehow different with teaching speaking to college students. The essential is the same, they can speak. But the way we teach and in what extent they can speak are different. College students are supposed to be able to communicate with friend even that is only simple conversation since they have learnt English since elementary school or even kindergarten.
Speaking is an activity used by someone to communicate with other. It takes place everywhere and has become part of our daily activities. When someone speaks, he or she interacts and uses the language to express his or her ideas, feeling and thought. He or she also shares information to other through communication (Ningtyas, 2014:1).

Speaking in college have reached the level of real communication where they have to implemented their skill to the real life and get used to used it in any situation. This need is not only for their 
academic activity which always ask them to be active on speaking in every meeting and get a good score in the last meeting, but also it hits the needs of the real life such as if they want to seek for a side job or if they just go around meeting foreigners and want to chat with them.

However, the students in second semester of STKIP Siliwangi Bandung still have hesitation on speaking in English. Most of them are still passive. Only several students who want to come up with something to say. Based on the pre-observation, the causes are various. First, they said that they have limited vocabulary. They stuck with what to say and cannot come up with something else to change the words. Limited vocabulary raises problem on students' speaking skill, since you can say very little with grammar, but you can say almost anything with words.

Second, their motivation is low. Their habit they brought from senior high school is that speaking is only done to gain score, either in daily assessment or in final exam. This habit trains their brain to be active only if the exam approaches. They will train, practice and study to gain a good score. But after that, they do not do it again. In result, after certain time they forget about what they had learnt for exam. It happens because speaking is a skill, and it needs to be practiced regularly, not in a particular time only.

Now, what makes students be more active and motivated to speak? One of the methods is by giving them task. As stated by Crookes (1986: 1), a task defines as a piece of work or an activity, usually with a specific objective, undertaken as a part of an educational course, at work, or used to elicit data for research.

By trying to accomplish the task, they will put all of their effort and try everything it takes to do that. This concept is suitable for students since it raise their willingness to think and to try something new. And, their motivation is always there, accomplishing task and gaining good scores.

The method involving task is Task-based instruction. Task-based Instruction refers to an approach based on the use of tasks as the core unit of planning and instruction in language teaching (Richards and Rodgers, 2001: 223). It belongs to process approach which emphasizes on the process rather than result.
Based on the problem mentioned above, the problem of the research is; how does the Taskbased instruction improve the students' speaking skill of the second semester students of STKIP Siliwangi Bandung in academic year of 20142015 ?

The aims of the study are as follows; (1) To describe how does the Task-based instruction improve the students' speaking skill of the second semester students of STKIP Siliwangi Bandung in academic year of 2014-2015

The benefits expected from the study include the following; (1) To give additional contribution to other education researches dealing with four basic English skills, especially speaking skill, (2) To give additional information to students to find the most suitable strategy to improve their speaking skill, (3) To give additional information to students and teachers about the effectiveness of Task-based instruction to improve students' speaking skill.

\section{B. THEORETICAL REVIEWS AND RESEARCH METHOD}

\section{Theoretical Reviews}

\section{a. Definition of speaking}

Speaking has many definitions based on experts. Here are some definitions about speaking based on some experts. Underwood (1996: 11) states that speaking means a creative process; an active interaction between speaker and listener that involves thought and emotion. Second, Brown (2007: 4) defines speaking as an interactive process of constructing meaning that involves producing, receiving and processing speech of sounds as the main instrument.

Then, Bygate (1997:vii) adds that speaking is a skill which deserve attention every bit as much as literacy skills, in both first and second language. Next, Lewis and Hill (1993:54) state that speaking is a process that covers many things in addition to the pronounciation of individual sounds. Last, Widdowson (1996:54) believes that speaking is simply the physical embodimant of abstract system or of the grammatical system of language or both. It means that the speakers have kept at least phonogical system and grammatical system in themselves.

It can be concluded that speaking is an oral expression of an interactive process of constructing 
meaning which involves phonological and grammatical system and requires the ability to cooperate in the management of speaking turn in order to give information and ideas.

\section{b. Definition of Task-based Instruction}

Task-based Instruction refers to an approach based on the use of tasks as the core unit of planning and instruction in language teaching (Richards and Rodgers, 2001: 223). Tasks are proposed as useful vehicles for applying this principle. As stated by Crookes (1986: 1), a task defines as a piece of work or an activity, usually with a specific objective, undertaken as a part of an educational course, at work, or used to elicit data for research.

Task-based Instruction belongs to process approach which emphasizes on the process rather than result. By doing the task, the students will be experiencing an activity which requires learners to arrive at an outcome from given information through some process of thought, and which allows teachers to control and regulate the process (Prabhu, 1987: 17). Long and Crookes (1991: 43) claim that tasks provide a vehicle for the presentation of appropriate target language samples to learners - input which they will inevitably reshape via application of general cognitive processing capacities - and for the delivery of comprehension and production opportunities of negotiable difficulty.

Many tasks will require learners to create and interpret messages for which they lack full linguistic resources and prior experience. In fact, this is said to be the point of such tasks. Richard and Rodgers (2001: 235) state that practice in restating, paraphrasing, using paralinguistic signals (where appropriate), and soon, will often be needed. The skills of guessing from linguistic and contextual clues, asking for clarification, and consulting with other learners may also need to be developed.

\section{Research Method}

The research was conducted to the second semester students of STKIP Siliwangi Bandung in the academic year of $2014 / 2015$, especially in class A2. There are 62 students in this class which consists of 54 girls and 8 boys. The writer chooses the secondsemester students because in the age level these students are supposed to be able to speak out the language as means of communication. Besides, this class is potential to improve their speaking. Moreover, in this level of study, college students must have a good ability in speaking since they are now in the English Department.

The method used in this research is classroom action research. As stated by Gregory, Kemmis and McTaggart (in Richard, 2000:12), action research is used to refer to teacher-initiated classroom investigation which seek to increase the teacher's understanding of classroom teaching and learning, and to bring about change in classroom practices. Richard and Lockhart (2000:12) add that action research is used to refer to teacher-initiated classroom investigation which seek to increase the teacher's understanding of classroom teaching and learning, and to bring about change in classroom practices.

Furthermore, Richard (1999: 12) states that action research typically involves small-scale investigative projects in the teachers' owm classroom, and consists of a number of phaseswhich often recur in cycles; planning, action, observation, and reflection are covered in one cycle. In a research, a researcher may have more than one or two cycle depends on how difficult the problem the writers face. Each cycle is followed by another cycle where the previews cycle is used as a basis of deciding what should be done in the next cycle.

The writers collected two kinds of data. The first one was quantitative data, and the second one was the qualitative data. Quantitative data refers to students' speaking scores that the writers took both in pre-test and in post-test. While qualitative data deals with any occurrences and changes happen during classroom activities such as students' behaviour, classroom situation andthe process of classroom activity. The researcher collected qualitative data by using observation, field notes, and interview. Observation is closely watching and noting classroom events, happening or interaction, either as a participant in the classroom (participant observation) or as an observer of another teacher classroom (non-participant observation).

Quantitative data, in this case students' speaking score is analyzed by searching the mean score in every test, pre-test 1 , post-test 2 and post-test 2 . Then the mean of score for each test is compared to now the improvement of the students quantitatively. Therefore, chances in students' quantitative achievement could be monitored. 
Qualitative data were analyzed by using Constant Comparative Method as suggested by Strauss and Glesser inMoleong (2004: 288-289). They say in general, the data analysis includes data reduction, data classification, data synthesis, and ended by action hypothesis.

\section{RESEARCH FINDINGS DISCUSSIONS}

AND

Through pre-observation, it can be known that the difficulty faces by the students in speaking are both their limited vocabulary and their lack of motivation. As stated before, their habit they brought from senior high school is that speaking is only done to gain score, either in daily assessment or in final exam. It raises problem on their capability on speaking.

As the proposed solution the writers come up with, Task-based instruction was implemented to improve their speaking skill. There are two cycles done in this research. Each cycle consists of two meetings. In each cycle there must be planning, acting, observing and reflecting. Before the writer applied the Task-based instruction method to teach, he conducted pre-test to figure out the students' ability on speaking. So, the arrangement is as follows: pre-test $\Rightarrow>$ cycle 1 (two meetings) $\Rightarrow$ post-test $1 /$ pre-test $2 \Rightarrow$ cycle 2 (two meetings) $=>$ post-test 2 .

In pre-test, the students still felt hesitate to speak in English, they worry to make mistakes. The scoring rubric used is from Hughes (2004: 131). The reason why the researcher used this scoring rubric is because it agrees with the aspects constructed by the researcher and it is the simplest one, so it can be applied easily by the researcher to obtain the speaking score of the students.

The mean score of pre-test was 4.3. It considers as not good result since they are supposed to be better than that.

The first cycle run so smoothly and the students really enjoyed the lessons. The students divided into ten groups which consist of 6-7 students for each group. As notice by the lecturer, the students had enjoyed the process of discussion. The task they have to accomplish relates to what business they may run in the future.

After discussion, they have to share the result in front of their classmates for each group. This activity was running for two meetings. After all of the groups presented their result, now it was the lecturer's turn to give them correction.

During did their discussion, they cooperated well. They helped each other to find some vocabularies and in arranging the sentences. They also made their correction to the wrong words they had made. The researcher also found out some points from their presentation. They are as follow: (1) most of the group did not use their own words, but only copied from the article and spoke it out; (2) they produced only few vocabularies, (3) they still pronounced the words doubtfully.

After the first treatment, there were things which are considered as positive results. Related to the first point they found, the students' motivation were getting better triggered by the task given. Then all they had to do was keeping the discussion alive, keep giving students genuine reason for them to speak. Giving students some topics which they know or learn before attracted their attention better. And the most important thing is those task can trigger their activeness in speaking.

Referring to what they identified as both positive and negative results, they planned to take a revised action which aimed to accomplish the target they had set. From the three points they wants to reach, each point have showed improvement, though there was just a little.

The first point is improvement of motivation showed by their sentences production. If they had been motivated, they would try to think more about producing words for building sentences. And in post- test 1 , it showed that their vocabularies, words and sentences were increased. They did not only present speaking based on they had already known, but also try to find out about more vocabularies for building sentences. Since if they did not know the meaning of a word in English, they will avoid using this word, or maybe they will avoid stating the sentences contained this word.

The second point is improvement of micro skill. During the treatment, the students sometimes did take and give vocabularies. It means that if a student did not know about such word, the other student told her. It helped the students to improve their vocabularies. In post-test 1 , it showed that their vocabularies enrichment was increased. It was showed by their presentation which had some new vocabularies on it. However, the improvement was far from being expected. 
It was glad for knowing that their vocabulary was increased, but it was different with their pronunciation, grammar and structure. It needed so many fixing.

The third point is improvement of their performance of speaking. In pre-test, they performed the speaking by sitting in the chair, but in post-test 1 , they had to perform by standing up in front of the classroom. Some students showed their improvement of self-confidence by performing a better presentation, but it was not a few students that still feel shy and nervous.

The second cycle also runs for two meetings. In the main activity, the students had to do discussion about art. The task was to find an example of art and comment it as if they are art critics. The group was the same group like in the cycle 1 .

During the discussion, he noticed what happened in each group, whether they did better or not. He also took a note for something important or interesting. And when there was a student need some helped, he must handle it

Same with the first cycle, after discussion they have to share what they have discussed in front of their classmates.

The writer observed some words which were mispronounced, some sentences which had wrong grammar, and some performances which still showed their nervousness. Beside, the writer also praised their good job, their awesome improvement and their willingness to do the task.

Then for the last session of the research, post-test was conducted. The students have to perform one by one and have to share about art, material which what they discussed before.On conducting the all meetings of cycle 2 , the writer also made a field note in order to notify all of the students' progress during the method application.

In the first meeting, when he conducted the second treatment by asking them to join the group, they still showed their enthusiasm. It means that their spirit of doing the discussion was still remained. It was good for them since they would be attracted on the lesson and made the treatment be more effective.

On doing the discussion, they did the vocabulary take and give, like in the first treatment. Since they did not have any paper related to the topic, they have to search and made their own sentences. It raised their creativity, since they were active to open their dictionary and discuss what words should be used in transferring their idea.

On delivering the presentation, it seem that they did it better. Their pronunciation was good, and their performance was much better too. Most of them did not show their nervous anymore, and the other groups show their respect by paying attention and did not be noisy like in the first presentation.

The second meeting of cycle 2 was run well too. There was not any disturbance, almost the students paid attention on the correction session. They also asked more question about how to pronounce some words.

In the third meeting, when the post-test be held, the students did not show over nervous like in the pretest and post-test 1 . They stayed calmly. And when they did their speech, they perform well and they could make the condition as comfortable as they wish. It gave good impact too for their speaking score at all.

The second treatment had been conducted well. In this treatment, the researcher did the same method with the first treatment, namely task-based instruction, but he made some alterations on conducting it. First, he told to change the spokesman in each group for giving opportunity to the other students to speak. Second, he added an extra time for the students to accomplish the task.

By doing this alterations, in fact, it can reduce the negative results. As stated in the previous reflection, the negative result out during the treatment were students' noisy and ignorance. Their noises affected the classroom climate and the process of presentation. But by doing that alteration, it can be reduced.

The improvements of the three points he wants to reach were increased too. They are the improvements of motivation, micro skill and performance of speaking. Their motivation shown must better, since they were happy in joining the class, it showed by their happy face, and they had willingness to search new vocabularies on their dictionary.

Beside, the improvement of their micro skill was increased too. Their pronunciation was good, but in grammar and structure there was just a little bit positive change. The improvements of micro skill can be proven through their score of post-test 2 .

Their performance was much better too. Since their nervousness during the speaking test was looked 
reducing. Over all, all of done in the second treatment gave advantages to the improvement of the students' speaking skill. By all of the improvement gained, the writer decided to take only two cycles for this research.

In this section, the writers want to discuss about what they had done during the research. From the treatment had been conducted, they believe that it is true that task-based instruction gives students opportunities to speak more. As stated before that the method chosen can enable the students to speak more.

In the early reflection which had done by the writers before conducting the research, it is known that the students at the second semester of STKIP Siliwangi Bandung stated that the most difficult skill to master is speaking. Through the "sit in" activity done by the writer, she observed what was happened during the English lesson. In fact, when their lecturer explained about some materials, they just stayed passive. Even when their lecturer tried to speak in English, there were only few students who responded. They did not have any willingness to speak. And when the writer asked them the reason through interview section, they stated that they feel ashamed and have limited vocabularies.

Based on the problem found out, the writers decided to use Task-based instruction method to improve their speaking skill. In the first treatment, when the writers told them that they had to stay in group to do a discussion, they were really happy. In group, they could help each other, and could practice about what they were going to speak.

There was a positive change. In group, they wanted to speak. It implied that their willingness to speak was increased. It was because they had more opportunities to speak in their each group.

In the second treatment, they were much better. If in the first treatment they still copied the vocabulary on their article they might find in the internet, in second treatment they could produced their own words related to the topic. It proved that in group the students can get a bigger opportunity to speak.

By doing the task, the students will be experiencing an activity which requires learners to arrive at an outcome from given information through some process of thought, and which allows teachers to control and regulate the process (Prabhu, 1987: 17). Long and Crookes (1991: 43) claim that tasks provide a vehicle for the presentation of appropriate target language samples to learners - input which they will inevitably reshape via application of general cognitive processing capacities - and for the delivery of comprehension and production opportunities of negotiable difficulty.

Before the writers conducted the treatment, their activeness was so low. They just keep quiet and only listened to what the lecturer said, since they did not know what to come up with. But in group, they had responsibility on their task and had to do it together with their friends. In the first treatment, it seemed that they could cooperate with their friend on their own group and it made them be more active. They also did the take-give vocabularies to the students that did not know about the meaning of such vocabularies.

In second treatment, the take-give vocabulary was increased, since they had to find their own words to build sentences represent their idea. They also could cooperate better and be more creative on creating their own statements.In observation, it seemed that there was no communication in English happened between the students during the English lesson. But in the first treatment, there was communication between the students through answer-question session. After they discussed the task, they conducted the presentation in front of their friend. On this presentation session, they delivered the result of the task they had accomplished. It was responded by their friends by asking answer and giving comment.

From what the researcher has discussed above, it is true that task-based instruction can improve the students' speaking skill. It can be seen from the score improvement happened after some treatments, from 4.3 became 6.5 , and finally became 7.6. It was an adequate positive change considering there was only a limit time in conducting the treatments. But even though it is not a great result, referring its criteria of assessment, time of research, and the students' level, it is not a failure.

The improvements of the students score of speaking is not the only one thing that shown to be the success of the research. More than it, the improvement of the students enthusiasms and their cheerfulness they shown during the research was the best thing that the writers got as their own satisfaction. Their happiness and spirit increased by this method also become the proof of the success that cannot be counted by thousand score. 
Beside this, be closer to the students is also an important thing for the lecturer since we can understand them and respect them as well.

\section{CONCLUSIONS}

Students' achievement in speaking which is measured quantitatively increased. It was known through pre-test, post-test 1 and post-test 2 . Before the treatment, the writer conducted pre-test, and the mean of pre-test was 4.3. After the first treatment, she conducted post-test 1 and the mean was 6.5. The last meeting of second treatment, she conducted post-test 2 , and the mean was 7.6. It showed that there is improvement on their result.

Task-based instruction method is carried out through task. Giving appropriate task brings up students' motivation on speaking out their ideas. Appropriate topics for the task mean the topics which are familiar and closely related to their world or their daily life. It becomes a genuine reason for them to speak; they feel that they want to speak. Genuine reason really brings them forward to speak because they know exactly what they speak about. It is not a matter of speaking to fulfill their task, but it is also the speaking which same with their daily topics chatted with their friend in the school.

To speak up the language, students must not be afraid of making mistakes. Mistakes are not to be afraid of it should be tolerated and taken from granted as people sometimes learn from mistakes. In task-based instruction method, students have to cooperate with other in order to accomplish the task. It means that they have to put their fear of making mistakes away to try their best to communicate their idea. Somehow, only spokesman deliver ideas, but after some steps of alteration, the other students have chances in delivering their ideas. They have to face their fears and start to talk even if they have limited vocabularies, poor grammar, and make many mistakes in the language they used.

In this research, one thing which makes students afraid of making mistakes isrelated to the knowledge of the language they have. In this case, their micro skill: Vocabularies, grammar, and pronunciation are identified as the obstacle for them to speak freely. However, those are the components of competence in speaking. Lack of vocabularies, grammar, and pronunciation reflect their limited competence of English speaking.
Task-based instruction helps students to deal with this through student to student and lecturer to students' exchanges and correction. Pronunciation correction and vocabularies enrichment happen naturally during the process of discussion. While the pronunciation and vocabularies drill at the end is only the way the writer strengthen what they already got. Somehow, it is not the guarantee that they would speak appropriately later, but it is indeed an eye opening effort for them to speak.

Then it comes to the students' communicative activeness in English speaking. At the beginning, it is hoped that the process of discussion would encounter students' communicative English speaking. But in fact, they still feel not confidence to speak in English and prefer to speak in Indonesia when they discussed about the material. The communication in English is not happened in their discussion. Therefore, it needs question and answer session after the presentation session.

The students, particularly college students who learn English should learn how to use the language in real. One of the ways to easily practice it is to experience task-based instruction. The keys are to pick up interesting tasks which are genuine reason for them to speak and not too afraid of making mistakes. Indeed, they can use task-based instruction in everyday live. Discussing their problems and findings out the solutions with their friends are some examples. If those are accomplished, communicative English speaking will flow as a river reaches ocean.

In conducting classroom activities, especially speaking activities, teacher should have several references of teaching techniques or methods. Task-based instruction is one of the methods. Conducting task-based instruction is as one of the alternative ways of promoting speaking activity to avoid the students' boredom. It gives students a non-threatening condition. As it is stated before, the key is giving appropriate tasks. For lecturers, they should encourage students to speak without fears and bring the procedures of leading taskbased instruction in a fun way.

The writers realize that this research gives a little knowledge only, so further researches are required. The study of improving students' speaking skill by doing task-based instruction from other point of view is needed to fulfill the need of this knowledge. Besides, in this study the writers only deal with the second semester students of STKIP Siliwangi Bandung with certain characteristics, 
whereas there are other grades of students with some other characteristics which are not analyzed here. Finally, the writers hope that the result of this study can stimulate other researchers to conduct other researches related to this field.

\section{E. REFERENCES}

Brown, H. Douglass. 2007. Principles of Language Learning and Teaching. New York: Pearson Education, Inc.

Bygate, martin. 1997. Speaking. New York : Oxford University Press.

Richard, Jack and Lockhart, Charles. 2000. Reflective Teaching in second language classroom. New York: Cambridge University Press.

Richards, Jack C., and Rodgers, Theodore S. 2001. Approaches and Methods in Language Teaching. Cambridge: Cambridge University Press.

Richards, J. C. 1997. The Language Teaching Matrix.Cambridge : The Press Syndicate of University of Cambridge.

Strauss, Anselm and Corbin, Juliet. 1990. Basics of Qualitative Research : Grounded Theory, Procedures, and Techniques. London : Sage Publications.

Underwood, M. 1996. Teaching Listening. New York: Longman, Inc.

Ur, Penny. 1996. A Course in Language Teaching, Practice and Theory. Cambridge: Cambridge University Press.

Widdowson, H. G. 1996. Teaching language as communication.Hongkong: Oxfort University Press. 